\title{
Analisis Status Kerusakan Tanah Pada Lahan Kering di Kampung Jawa Dusun Kabo Jaya, Sangatta
}

\author{
Mufti Perwira Putra ${ }^{1}$ dan Muli Edwin² \\ ${ }_{1}$ Program Studi Kehutanan Sekolah Tinggi Pertanian Kutai Timur \\ Email : muftiotie@gmail.com \\ 2 Program Studi Kehutanan Sekolah Tinggi Pertanian Kutai Timur \\ Email : muliedwin@stiperkutim.ac.id
}

\begin{abstract}
This study aimed to analyze the status of soil degradation in Kampung Jawa, Village of Kabo Jaya, Sub-district of North Sangatta, East Kutai. The study was performed for approximately 3 months from July until September 2016. This study was based on soil survey method, soil sampling and field observation. The determination of land damage status referred to the regulation of the State Minister for the Environment, year of 2006, about Measurement Procedure of Land Damage Standard Criteria for Biomass Production. The sites study were in two locations of cultivated lands, the first one was 15 years old of teak plantation area, and the other was former garden shrubs. Both lands had similar characteristics, especially topography. The type of soil in both locations was acidic. Of the 10 parameters used to assess the status of soil damage, there were 2 parameters that exceed the critical threshold, which were $\mathrm{pH}$ and $\mathrm{DHL}$, implied that those two locations had declining in land quality, especially in biomass production. Therefore there had to be an effort to conserve or repair land, especially to reduce the acidity of the soil.
\end{abstract}

Keywords: teak, soil, cultivation, conservation

\begin{abstract}
ABSTRAK
Penelitian ini bertujuan untuk menganalisis status kerusakan tanah di Kampung Jawa Dusun Kabo Jaya Kecamatan Sangatta Utara. Penelitian dilaksanakan selama kurang lebih 3 bulan dari bulan Juli sampai September 2016. Penelitian ini berdasarkan metode survei tanah, pengambilan sampel tanah dan pengamatan lapangan. Kemudian penetapan status kerusakan tanah mengacu pada peraturan Menteri Negara Lingkungan Hidup Tahun 2006 Tentang Tata Cara Pengukuran Kriteria Baku Kerusakan Tanah Untuk Produksi Biomassa. Kedua lokasi penelitian merupakan lahan budidaya, pertama adalah lahan tanaman Jati yang berumur 15 tahun, kedua adalah lahan semak bekas kebun. Kedua lahan tersebut memiliki karakteristik yang hampir sama, terutama topografi. Tanah di kedua lokasi merupakan jenis tanah masam. Dari 10 parameter yang digunakan untuk menilai status kerusakan tanah, terdapat 2 parameter yang melebihi ambang kritis, yaitu $\mathrm{pH}$ dan $\mathrm{DHL}$, sehingga kedua lokasi merupakan lahan yang telah mengalami penurunan kualitas, terutama dalam produksi biomassa. Oleh karena itu perlu ada upaya konservasi atau perbaikan lahan terutama untuk mengurangi tingkat keasaman tanah.
\end{abstract}

Kata kunci: jati, tanah, budidaya, konservasi

\section{Pendahuluan}

Lahan atau tanah merupakan sumber daya alam yang dimanfaatkan untuk berbagai kepentingan berusaha dan untuk kehidupan. Sumber daya lahan tidak dapat dipisahkan dengan tanah yang ada pada lahan tersebut di samping faktor-faktor luar yang akan mempengaruhinya. Tanah merupakan media tumbuh bagi tanaman atau suatu komoditas yang diusahakan. Banyak orang hanya melihat tanah sebagai media tumbuh yang berupa lapisan atas, hanya berupa dimensi permukaan atau satu dimensi saja dan 
tidak melihat lebih lanjut tentang apa yang ditemukan di bagian dalam dan kondisi permukaan sekitarnya. Mencatat keadaan tanah di suatu tempat tidaklah cukup hanya mencatat tentang tekstur, warna dan $\mathrm{pH}$, tetapi harus meliputi seluruh karakter tanah secara implisit, termasuk di antaranya klasifikasi tanahnya (Heryani, 1994).

Populasi untuk dunia masa depan akan selalu membutuhkan persedian makanan, yang mana sekitar 99,7\% makanan manusia untuk memenuhi kebutuhan kalori berasal dari tanah, sementara kurang dari $0,3 \%$ berasal dari lautan dan ekosistem air lainnya (FAO, 2013). Mempertahankan dan menambah pasokan pangan dunia pada dasarnya tergantung pada produktivitas dan kualitas tanah. Penurunan kualitas tanah dapat mengurangi produktivitas alam, pertanian dan kehutanan. Selain itu, tanah juga berperan penting untuk tingkat keanekaragaman tumbuhan, hewan dan mikroba dalam tanah (Pimentel, 2006).

Informasi terkait tingkat kerusakan tanah dan potensi serta konservasi lahan masih belum banyak diteliti dan dipelajari secara komprehensif, sehingga diperlukan program konservasi lahan dan tanah dengan penggalian informasi tentang kondisi lahan termasuk tingkat kerusakan tanah terutama pada lahan pertanian dan perkebunan masyarakat. Karena kedua hal tersebut memiliki peranan penting sebagai pemasok kebutuhan akan pangan di masa yang akan datang dan stabilitas ekonomi di Kabupaten Kutai Timur (BLH, 2015). Adanya kekhawatiran terhadap laju tingkat kerusakan tanah untuk produksi biomassa, maka pemerintah telah mengeluarkan kebijakan terkait hal tersebut yaitu pada Peraturan Pemerintah Republik Indonesia Nomor 150 Tahun 2000 tentang Pengendalian Kerusakan Tanah untuk Produksi Biomassa dan Peraturan Menteri Negara Lingkungan Hidup Nomor 07 Tahun 2006 tentang Tata Cara Pengukuran Kriteria baku Kerusakan Tanah untuk Produksi Biomassa.

Penelitian ini bertujuan untuk mengetahui Analisis Status Kerusakan Tanah pada lahan kering khususnya lahan bekas kebun dan lahan tanaman Jati di Kampung Jawa, Dusun Kabo Jaya, Kecamatan Sangatta Utara, Provinsi Kalimantan Timur.

\section{Metode Penelitian}

Waktu penelitian yang diperlukan untuk penelitian ini kurang lebih enam bulan, mulai dari bulan Juli 2016 sampai September 2016. Penelitian dilaksanakan di Kampung Jawa, Dusun Kabo Jaya, Kecamatan Sangatta Utara, Kabupaten Kutai Timur.

Metode yang digunakan dalam kegiatan ini adalah metode survei fisiografi terpilih, yaitu dengan melakukan pengamatan dan pengambilan sampel tanah secara langsung di lapangan yang lokasinya secara sengaja dipilih, dilanjutkan dengan analisis laboratorium. Pengamatan dan pengambilan sampel tanah dilakukan pada lokasi yang telah ditentukan berdasarkan peta kerja. Sampel tanah yang diambil terdiri atas dua jenis yaitu sampel tanah utuh (undisturbed soil sample) dan sampel tanah terganggu (disturbed soil sample). 
Survei utama dilakukan sesuai dengan waktu yang telah ditentukan. Beberapa kegiatan yang dilakukan dalam survei utama adalah:

\section{Mengadakan Pengamatan Lapangan}

Pengamatan lapangan meliputi pengamatan profil tanah untuk mengetahui ketebalan solum tanah, batuan dan lainnya sesuai kebutuhan penelitian ini. Untuk pengamatan karakteristik tanah yang diamati meliputi: ketebalan horizon, warna, tekstur, keadaan batuan, kedalaman efektif, drainase tanah dan solum tanah. Identifikasi dilakukan dengan jalan pengeboran atau lainnya, misalnya pengamatan pada tebing jalan atau bekas longsoran, yang bertujuan untuk mengenal satuan taksonomi.

\section{Pengambilan Contoh Tanah}

Setelah dilakukan deskripsi profil, diteruskan dengan pengambilan contoh tanah. Untuk tujuan analisis beberapa sifat fisik tanah, diambil contoh tanah utuh menggunakan "ring sample" disertai dengan pemberian label.

a) Contoh tanah utuh ditujukan untuk analisis permeabilitas tanah, porositas, kerapatan lindak/berat jenis tanah.

b) Kemudian pengambilan contoh tanah tidak utuh, untuk analisis beberapa parameter tanah seperti jumlah mikroba, redoks, KTK, C-organik, DHL, Kejenuhan Basa, Kejenuhan Alumunium dan Pirit serta $\mathrm{pH} \mathrm{H}_{2} \mathrm{O}$.

c) Untuk tanah utuh pengambilan sampel dilakukan pada kedalaman 0-10, 10-20 dan 20$30 \mathrm{~cm}$, kemudian untuk tanah tidak utuh pengambilan sampelnya dilakukan pada kedalaman 0-20 cm.

d) Sebaran pengambilan contoh tanah ini disesuaikan dengan keadaan fisiografi, bahan induk dan satuan taksonomi tanahnya.

Tabel 1. Kriteria Status Kerusakan Tanah di Lahan Kering

\begin{tabular}{|c|c|c|c|c|}
\hline No. & Parameter & $\begin{array}{l}\text { Ambang kritis } \\
\text { (PP 150/2000) }\end{array}$ & $\begin{array}{c}\text { Hasil } \\
\text { pengamatan/analisis }\end{array}$ & $\begin{array}{c}\text { Melebihi/ } \\
\text { tidak }\end{array}$ \\
\hline 1 & Ketebalan solum & $<20 \mathrm{~cm}$ & $\mathrm{Cm}$ & \\
\hline 2 & Kebatuan permukaan & $>40 \%$ & $\%$ & \\
\hline 3 & Komposisi fraksi & $\begin{array}{c}<18 \% \text { koloid; } \\
>80 \% \text { pasir kuarsitik }\end{array}$ & $\%$ & \\
\hline 4 & Berat isi/kerapatan lindak & $>1,4 \mathrm{~g} / \mathrm{cm}^{3}$ & $\mathrm{~g} / \mathrm{cm}^{3}$ & \\
\hline 5 & Porositas total & $<30 \% ;>70 \%$ & $\%$ & \\
\hline 6 & $\begin{array}{l}\text { Derajat pelulusan air / } \\
\text { permeabilitas }\end{array}$ & $\begin{array}{l}<0,7 \mathrm{~cm} / \mathrm{jam} ; \\
>8,0 \mathrm{~cm} / \mathrm{jam}\end{array}$ & $\mathrm{cm} / \mathrm{jam}$ & \\
\hline 7 & $\mathrm{pH}\left(\mathrm{H}_{2} \mathrm{O}\right) 1: 2,5$ & $<4,5 ;>8,5$ & & \\
\hline 8 & Daya hantar listrik/ DHL & $>4,0 \mathrm{mS} / \mathrm{cm}$ & $\mathrm{mS} / \mathrm{cm}$ & \\
\hline 9 & Potensial redoks & $<200 \mathrm{mV}$ & $\mathrm{mV}$ & \\
\hline 10 & Jumlah mikroba & $<10^{2} \mathrm{cfu} / \mathrm{g}$ tanah & cfu/g tanah & \\
\hline
\end{tabular}

Analisis status kerusakan tanah mengadopsi metode yang dikeluarkan oleh Kementerian Lingungan Hidup, yaitu PERMENLH Nomor 19 Tahun 2008. Data dianalisis untuk memperoleh informasi mengenai status kerusakan tanah. Hasil analisis yang 
dilakukan secara tabular, selanjutnya dikaitkan dengan data spasialnya untuk menghasilkan data spasial potensi kerusakan tanah, sedangkan status kerusakan tanah untuk produksi biomassa dianalisis berdasarkan Tabel.

\section{Hasil dan Pembahasan}

Kecamatan Sangatta Utara merupakan salah satu kecamatan yang berada di Kabupaten Kutai Timur. Terbentuk pada tahun 1970. Seiring perkembangan waktu dan atas tuntutan reformasi sejak tahun 1998, Lahirlah Undang-Undang Nomor 47 Tahun 1999, tentang pembentukan Kabupaten Kutai Timur dari pemekaran Dati II Kutai pada tanggal 12 Oktober 1999. Kecamatan Sangatta Utara sebelumnya terdiri atas 14 desa setelah pemekaran menjadi 22 desa (BPS Kutai Timur, 2016). Kecamatan Sangatta Utara memiliki luas wilayah $308,52 \mathrm{~km}^{2}$ dengan jumlah penduduk Kecamatan Sangatta Utara saat ini kurang lebih 90.152 jiwa. Masyarakat Sangatta Utara bekerja di berbagai sektor seperti sektor pertambangan, pertanian, perdagangan, pegawai pemerintahan, nelayan, pengrajin, buruh, pensiunan dan lain sebagainya. Sejalan dengan perkembangan, lahirnya Perda Kabupaten Kutai Timur tahun 2005 tanggal 31 Oktober 2005, Kecamatan Sangatta Utara dimekarkan menjadi 4 desa terdiri atas: Desa Sangatta Utara, Desa Teluk Lingga, Desa Singa Gembara dan Desa Swarga Bara. (BPS Kutai Timur, 2016)

Beberapa karakteristik lahan di lokasi penelitian adalah sebagai berikut.

Tabel 2. Karakteristik Umum Lahan di Kebun Jati

\begin{tabular}{cll}
\hline No. & \multicolumn{1}{c}{ Karakteristik lahan } & \multicolumn{1}{c}{ Hasil pengamatan/penilaian } \\
\hline 1 & Jenis tanah (great group) & Ultisols \\
\hline 2 & Vegetasi dominan & Jati \\
\hline 3 & Sifat bulan ini & Lembap \\
\hline 4 & Fisiografi & Lereng kaki bukit \\
\hline 5 & Relief makro & Berbukit \\
\hline 6 & Kemiringan lahan & Agak curam \\
\hline 7 & Panjang lereng & \pm 60 m \\
\hline 8 & Arah lereng & Barat \\
\hline 9 & Drainase tanah & Permukaan: sangat cepat; Vertikal: lambat \\
\hline 10 & Keadaan permukaan tanah & Bahan kasar: kerikil; sebaran: merata \\
\hline
\end{tabular}

Kebun jati adalah kawasan budidaya tanaman perkebunan milik masyarakat sekitar yang sebagian besar masyarakat membudidayakan tanaman keras seperti jati, karet dan tanaman kayu lainnya, sehingga kondisi lahan terbuka memang sangat sedikit. Tipe-tipe penggunaan lahan di Kutai Timur saat ini didominasi oleh sektor perkebunan, pertambangan, pertanian dan hutan tanaman. Semua itu berpengaruh terhadap perubahan tanah di masa mendatang termasuk terhadap perubahan iklim.

Tabel 3. Karakteristik Umum Lahan di Areal Bekas Kebun

\begin{tabular}{cll}
\hline No. & \multicolumn{1}{c}{ Karakteristik lahan } & \multicolumn{1}{c}{ Hasil pengamatan/penilaian } \\
\hline 1 & Jenis tanah (great group) & Ultisols \\
\hline 2 & Vegetasi dominan & Tumbuhan semak \\
\hline 3 & Sifat (bulan) & Lembap \\
\hline
\end{tabular}




\begin{tabular}{cll}
\hline 4 & Fisiografi & Lereng kaki bukit \\
\hline 5 & Relief makro & Bergelombang \\
\hline 6 & Kemiringan lahan & Miring \\
\hline 7 & Panjang lereng & $\pm 50 \mathrm{~m}$ \\
\hline 8 & Arah lereng & Selatan \\
\hline 9 & Drainase tanah & Permukaan: sangat cepat; Vertikal: lambat \\
\hline 10 & Keadaan permukaan tanah & Bahan kasar: kerikil; sebaran: merata \\
\hline
\end{tabular}

Selanjutnya untuk gambaran umum lokasi penelitian pada lahan bekas kebun paling banyak didominasi tumbuhan semak/belukar. Kondisi tersebut akan memiliki dampak yang besar terhadap kerusakan tanah apabila dalam pemanfaatan kurang memperhatikan kaedah-kaedah konservasi. Pada lokasi kedua ini, tidak jauh berbeda dengan hasil pengamatan pada lahan kebun Jati dengan luas lahan yang hampir sama dan berada pada satu areal atau kawasan yang sama.

\section{Kondisi Fisik-Kimia Tanah di Lokasi Penelitian}

Berdasarkan pengamatan lapangan dan hasil analisis laboratorium, maka dapat diketahui beberapa kondisi fisik tanah di lahan kebun Jati dan lahan bekas kebun (semak). Menurut Hardjowigeno (2007), ordo tanah Ultisol merupakan tanah tua, yang mana terjadi penimbunan liat di horizon bawah permukaan. Menurut Subroto (2003), tanah Ultisol memiliki sebaran yang luas di Kalimantan Timur, yaitu sekitar $70 \%$ dari luas wilayah daratan Kaltim. Kedua lahan di lokasi penelitian yang berdekatan memiliki karakteristik fisik tanah yang hampir sama, karena berada pada hamparan lahan yang sama seperti digambarkan pada Tabel 4.

Tabel 4. Kondisi Fisik Tanah Daerah Studi

\begin{tabular}{|c|c|c|c|}
\hline \multirow{2}{*}{ No. } & \multirow{2}{*}{ Sifat fisik tanah } & \multicolumn{2}{|c|}{ Lahan } \\
\hline & & Kebun Jati & Bekas kebun (Semak) \\
\hline 1 & Ketebalan solum (cm) & 60 & 70 \\
\hline 2 & Warna tanah & & \\
\hline 3 & Porositas (\%) & 40,21 & 42,98 \\
\hline 4 & Permeabilitas cm/jam³) & 0,5111 & 4,9655 \\
\hline 5 & Kerapatan lindak $\left(\mathrm{g} / \mathrm{cm}^{3}\right)$ & 1,24 & 1,26 \\
\hline 6 & Tekstur tanah (\%) & $\mathrm{SiCL}$ & $\mathrm{SiCL}$ \\
\hline & • Liat & 36,14 & 33,27 \\
\hline & - $\quad$ Debu & 50,65 & 56,48 \\
\hline & - $\quad$ Pasir & 13,21 & 10,25 \\
\hline
\end{tabular}

Ket: SiCL: Silty clay loam (lempung liat berdebu)

Ketebalan solum atau kedalaman lapisan tanah berbeda tipis seperti yang terlihat pada Tabel 4. Selain itu, tekstur tanahnya adalah lempung berpasir yang didominasi oleh partikel pasir, tetapi cukup mengandung tanah liat dan sedimen untuk menyediałkan beberapa struktur dan kesuburan tanah. Kandungan fraksi tanah (tekstur) sangat berpengaruh terhadap konsistensi tanah atau keeratan tanah. Tanah yang bertekstur pasir sangat sulit menyerap (menahan) air dan unsur hara, sedangkan tanah yang bertekstur liat memiliki kemampuan besar menyerap air dan unsur hara. Persentasi fraksi tanah juga memiliki kemampuan untuk menahan tumbukan air hujan dan penghanyutan oleh aliran air hujan yang mengalir di atas permukaan tanah(run-off). Untuk tingkat kesuburan kimiawi 
tanah dari beberapa sifat-sifat kimia tanah hasil analisis laboratorium, dapat diketahui pada daerah studi.

Jenis tanah lempung berpasir didominasi oleh partikel pasir, tetapi cukup mengandung tanah liat dan sedimen untuk menyediakan beberapa struktur dan kesuburan. Tanah lempung berpasir memiliki konsentrasi tinggi. Di kebun dan rumput, tanah lempung berpasir mampu dengan cepat menguras kelebihan air tetapi tidak dapat menahan sejumlah besar air atau nutrisi bagi tanaman.

Tabel 5. Kondisi Kimia Tanah Daerah Studi

\begin{tabular}{|c|c|c|c|}
\hline \multirow{2}{*}{ No. } & \multirow{2}{*}{ Sifat kimia tanah } & \multicolumn{2}{|c|}{ Lahan } \\
\hline & & Kebun Jati & Bekas kebun (Semak) \\
\hline 1 & KTK & 13,9 & 11,0 \\
\hline 2 & $\mathrm{DHL}(\mathrm{mS} / \mathrm{cm})$ & 0,030 & 0,032 \\
\hline 3 & Redoks (mV) & 291 & 280 \\
\hline 4 & C-organik (\%) & 0,98 & 0,94 \\
\hline 5 & $\mathrm{pH}$ & 3,8 & 4,36 \\
\hline 6 & Kejenuhan basa & 39,2 & 36,0 \\
\hline \multirow[t]{3}{*}{7} & Mikroba (cfu/g tanah) & & \\
\hline & -Bakteri & $8,4 \times 10^{4}$ & $4,0 \times 10^{4}$ \\
\hline & - Jamur & $7,0 \times 10^{3}$ & $4,0 \times 10^{3}$ \\
\hline \multirow[t]{5}{*}{8} & Kation basa & & \\
\hline & $\bullet \mathrm{Ca}^{++}$ & 4,22 & 3,09 \\
\hline & - $\mathrm{Mg}^{++}$ & 0,45 & 0,37 \\
\hline & $\bullet \mathrm{K}^{+}$ & 0,49 & 0,22 \\
\hline & - $\mathrm{Na}^{+}$ & 0,27 & 0,26 \\
\hline
\end{tabular}

Berdasarkan hasil analisis laboratorium, jumlah mikroba baik bakteri dan jamur di dalam tanah cukup tinggi seperti disajikan pada Tabel 5. Jumlah mikroba di dalam tanah sangat penting peranannya untuk membantu dan mempercepat proses dekomposisi secara biokimia yang hasilnya berupa kompos. KTK tanah sangat penting untuk menilai kesuburan tanah maupun genesis tanah. KTK merupakan sifat kimia yang sangat erat hubungannya dengan kesuburan tanah, yang mana tanah yang memiliki nilai KTK rendah memiliki kemampuan yang rendah untuk menyerap dan menyediakan unsur hara bagi tanaman (Hardjowigeno, 2013). Selain itu jumlah mikroba dan redoks serta DHL juga dijadikan sebagai parameter penting dalam menentukan status kerusakan tanah.

\section{Status Kerusakan Tanah di Lokasi Penelitian}

Menurut Undang-Undang RI No. 23 Tahun 1997 tentang Pengelolaan Lingkungan Hidup, sumber daya alam dibagi ke dalam sumber daya hayati biotik baik hewan maupun tumbuhan, dan sumber daya alam non hayati seperti tanah, udara, air dan lain-lain. Tanah merupakan sumber daya alam yang dapat diperbaharui tetapi membutuhkan rentang waktu yang lama. Tanah memiliki peranan strategis, baik untuk saat ini maupun masa depan.

Penduduk di Kabupaten Kutai Timur sebagian besar mengandalkan hidupnya dari sektor pertanian dan perkebunan, oleh sebab itu dalam pemanfaatan tanah atau lahan harus ada upaya dalam pemanfaatan tanah atau harus ada upaya terhadap pengendalian kerusakan tanah untuk menjaga kelestarian dan produksi biomassa yang berkelanjutan. 
Kerusakan tanah akan menyebabkan berkurangnya kemampuan tanah untuk mendukung pertumbuhan atau perkembangan tumbuhan atau menghasilkan barang dan jasa.

Lahan itu sendiri merupakan suatu lingkungan fisik yang meliputi tanah, iklim, relief, hidrologi dan vegetasi, yang mana faktor-faktor tersebut mempengaruhi potensi dan menjadi pembatas dalam pendayagunaannya. Sebagai contoh, kualitas suatu lahan sesuai untuk pertanian, maka lahan tersebut semestinya dimanfaatkan untuk pertanian (Klingiebel dan Montgomery 1961; Hardjowigeno dan Widiatmaka 2007). Berubahnya sifat atau karakteristik tanah dalam hubungannya dengan produksi biomassa dapat disebabkan oleh berbagai hal seperti tindakan pengolahan tanah yang tidak memperhatikan kaedah konservasi, pemupukan yang berlebihan, pemanfaatan tanah yang terus-menerus dalam waktu yang lama atau pemanfaatan lahan yang tidak sesuai dengan kemampuan lahan itu sendiri. Oleh karena itu kerusakan tanah menjadi perhatian pemerintah dan menetapkan kriteria baku kerusakan tanah untuk produksi biomassa yang tertuang dalam Peraturan Pemerintah RI Nomor 150 tahun 2000. Kriteria baku yang digunakan untuk menentukan status kerusakan tanah tersebut mencakup sifat fisik, kimia dan biologi tanah sebagaimana yang diadopsi dalam kegiatan ini.

Untuk penetapan status kerusakan tanah mengacu kepada Peraturan Menteri Negara Lingkungan Hidup Nomor 07 Tahun 2006 tentang tata cara pengukuran kriteria baku kerusakan tanah untuk produksi biomassa. Penetapan status kerusakan tanah untuk produksi biomassa perlu dilakukan sebagai salah satu upaya untuk pengendalian kerusakan tanah suatu daerah. Kriteria baku yang digunakan untuk menentukan status kerusakan tanah untuk produksi biomassa didasarkan pada parameter kunci sifat dasar tanah yang mencakup sifat fisik, sifat kimiawi dan sifat biologi tanah (BLH 2006).

Sifat dasar tanah menentukan kemampuan tanah dalam menyediakan air dan unsur hara yang cukup bagi kehidupan (pertumbuhan dan perkembangan) tumbuhan. Dengan mengetahui sifat dasar tanah, maka dapat ditentukan status kerusakan tanah untuk produksi biomassa. Tata cara pengukuran kriteria baku kerusakan tanah untuk produksi biomassa disusun untuk menjelaskan hal-hal yang harus dilakukan oleh kepala daerah atau instansi yang berwenang dalam melaksanakan pengukuran kriteria baku kerusakan tanah untuk produksi biomassa yang nantinya berkaitan dengan pemantauan dan pengawasan.

Tabel 6. Hasil Analisis Status Kerusakan Tanah Kebun Jati di Kampung Jawa Sangatta Utara

\begin{tabular}{clccc}
\hline No. & \multicolumn{1}{c}{ Parameter } & $\begin{array}{c}\text { Ambang kritis (PP } \\
\text { 150/2000) }\end{array}$ & $\begin{array}{c}\text { Hasil } \\
\text { pengamatan }\end{array}$ & Ket. \\
\hline 1. & Ketebalan solum & $<20 \mathrm{~cm}$ & $60 \mathrm{~cm}$ & Tidak \\
\hline 2. & Kebatuan permukaan & $>40 \%$ & $1,0 \%$ & Tidak \\
\hline 3. & Komposisi fraksi/tekstur & $\begin{array}{c}<18 \% \text { koloid; } \\
>80 \% \text { pasir kuarsitik }\end{array}$ & $10,25 \%$ & Tidak \\
\hline 4. & Berat isi & $>1,4 \mathrm{~g} / \mathrm{cm}^{3}$ & $1,2 \mathrm{~g} / \mathrm{cm}^{3}$ & Tidak \\
\hline
\end{tabular}




\begin{tabular}{clccc}
\hline 5. & Porositas total & $<30 \% ;>70 \%$ & $40,21 \%$ & Tidak \\
\hline 6. & Derajat pelulusan air & $<0,7 \mathrm{~cm} / \mathrm{jam} ;>8,0 \mathrm{~cm} / \mathrm{jam}$ & $0,503 \mathrm{~cm} / \mathrm{jam}$ & Melebihi \\
\hline 7. & ph $\left(\mathrm{H}_{2} \mathrm{O}\right) 1: 2,5$ & $<4,5 ;>8,5$ & 3,85 & Tidak \\
\hline 8. & Daya hantar listrik & $>4,0 \mathrm{mS} / \mathrm{cm}$ & $0,030 \mathrm{mS} / \mathrm{cm}$ & Tidak \\
\hline 9. & Potensi redoks & $<200 \mathrm{mV}$ & $291 \mathrm{mV}$ & Tidak \\
\hline 10. & Jumlah mikroba & $<\mathrm{cfu} / \mathrm{g}$ tanah & $15,4 \times 10^{7}$ & Tidak \\
\hline
\end{tabular}

Berdasarkan Tabel 6, dari 10 parameter terdapat 1 parameter yang melebihi ambang batas yang ditetapkan dalam Peraturan Menteri Negara Lingkungan Hidup Nomor 07 Tahun 2006 tentang tata cara pengukuran kriteria baku kerusakan tanah untuk produksi biomassa. Seperti penelitian yang dilakukan sebelumnya pada kerusakan tanah di Baru Ampar, dengan hasil yang diperoleh untuk Derajat Pelulusan Air 0,088 cm/jam. Untuk daerah Batu Ampar merupakan areal budidaya tanaman tahunan yang diusahakan oleh masyarakat berupa kebun lada. Areal tersebut memiliki tingkat kelerengan yang curam, sehingga menjadi wajar beberapa parameter melebihi ambang baku mutu.

Tabel 7. Hasil Analisis Status Kerusakan Tanah Semak Belukar di Kampung Jawa Sangatta Utara

\begin{tabular}{clccc}
\hline No. & \multicolumn{1}{c}{ Parameter } & $\begin{array}{c}\text { Ambang kritis (PP } \\
\mathbf{1 5 0 / 2 0 0 0 )}\end{array}$ & $\begin{array}{c}\text { Hasil } \\
\text { pengamatan }\end{array}$ & Ket. \\
\hline 1. & Ketebalan solum & $<20 \mathrm{~cm}$ & $70 \mathrm{~cm}$ & Tidak \\
\hline 2. & Kebatuan permukaan & $>40 \%$ & $0,1 \%$ & Tidak \\
\hline 3. & Komposisi fraksi & $<18 \%$ koloid; & $13,21 \%$ & Tidak \\
\hline 4. & Berat isi & $>1,4 \mathrm{~g} / \mathrm{cm}^{3}$ & $1,26 \mathrm{~g} / \mathrm{cm}^{3}$ & Melebihi \\
\hline 5. & Porositas total & $<30 \% ;>70 \%$ & 42,98 & Tidak \\
\hline 6. & Derajat pelulusan air & $<0,7 \mathrm{~cm} / \mathrm{jam} ;>8,0 \mathrm{~cm} / \mathrm{jam}$ & $4,965 \mathrm{~cm} / \mathrm{jam}$ & Melebihi \\
\hline 7. & ph $\left(\mathrm{H}_{2} \mathrm{O}\right) 1: 2,5$ & $<4,5 ;>8,5$ & 4,36 & Tidak \\
\hline 8. & Daya hantar listrik & $>4,0 \mathrm{mS} / \mathrm{cm}$ & $0,032 \mathrm{mS} / \mathrm{cm}$ & Tidak \\
\hline 9. & Potensi redoks & $<200 \mathrm{mV}$ & $280 \mathrm{mV}$ & Tidak \\
\hline 10. & Jumlah mikroba & $<\mathrm{cfu} / \mathrm{g} \mathrm{tanah}$ & $8,0 \times 10^{7}$ & Tidak \\
\hline
\end{tabular}

Selanjutnya, berdasarkan Tabel 7, dari 10 parameter terdapat 2 parameter yang melebihi ambang batas yang ditetapkan dan mengacu pada PERMENLH No. 20 Tahun 2008 yang dilakukan dengan menumpangsusunkan (overlay) beberapa data spasial (parameter penentu potensi kerusakan tanah). Seperti hasil evaluasi pada status kerusakan tanah di Long Masangat, di mana derajat pelulusan air 0,073 cm/jam. Tanah tersebut memiliki sebaran yang paling luas di Kaltim dan merupakan tanah tua dengan tingkat kesuburan yang rendah dan telah mengalami tingkat pencucian tanah yang tinggi (BLH 2016).

\section{Usaha Perbaikan Fisik-Kimia Tanah}

Pada Peraturan Daerah Provinsi Kalimantan Timur nomor 1 tahun 2014 tentang Perlindungan dan Pengelolaan Lingkungan Hidup dijelaskan, bahwa setiap penanggung jawab usaha dan/atau kegiatan yang dapat menimbulkan kerusakan tanah untuk produksi biomassa wajib melakukan pencegahan dan penanggulangan kerusakan tanah. Setiap penanggung jawab usaha dan/atau kegiatan yang mengakibatkan kerusakan tanah untuk produksi biomassa wajib melakukan pemulihan kondisi tanah. Pencegahan dan 
penanggulangan dampak pencemaran tanah merupakan dua tindakan yang tidak dapat dipisahkan, dalam arti kedua tindakan dilakukan untuk saling mengisi, apabila tindakan pencegahan sudah tidak dapat dilakukan, maka dilakukan penanggulangan kerusakan tanah untuk produksi biomassa (BLH 2015).

a) Pemerintah daerah harus memiliki peraturan daerah (Perda) terkait.

b) Melakukan evaluasi secara periodik untuk pengendalian atau pencegahan kerusakan tanah.

c) Secara intensif melakukan penanggulangan kerusakan tanah untuk memulihkan kerusakan tanah.

d) Melakukan evaluasi dan verifikasi terhadap laporan-laporan tentang kerusakan tanah dari masyarakat.

e) Menetapkan skala prioritas terhadap daerah yang memiliki potensi kerusakan tanah untuk produksi biomassa.

Pada prinsipnya tindakan pencegahan atau pengendalian adalah berusaha untuk tidak menyebabkan terjadinya kerusakan tanah dan atau meningkatkan kerusakan tanah. Ada beberapa hal yang dapat dilakukan terkait dengan pencegahan kerusakan tanah menurut BLH (2015):

a) Pengendalian dan pengolahan sampah rumah tangga.

b) Mengurangi penggunaan bahan-bahan yang tidak dapat diuraikan oleh mikroorganisme (nonbiodegradable).

c) Melakukan proses pemurnian terhadap limbah industri sebelum dibuang ke sungai atau ke tempat pembungan.

d) Penggunaan pupuk, pestisida sesuai dengan aturan, misalnya hindari teknik penyemprotan yang salah misalnya menyemprot berlawanan dengan arah angin, tidak menggunakan obat melebihi takaran.

e) Mengurangi pemberian izin terhadap pemanfaatan lahan skala luas dan penerapan teknologi untuk produksi biomassa.

f) Pemanfaatan energi alternatif, untuk mengurangi kebutuhan energi dari sumber daya alam seperti batu bara.

g) Membuat suatu program yang berkelanjutan mengenai pendidikan lingkungan.

Dalam Peraturan Daerah Provinsi Kalimantan Timur nomor 1 tahun 2014 ada empat cara yang dilakukan untuk penanggulangan kerusakan tanah yang disebut sebagai konservasi kualitas tanah, yaitu:
a. Rehabilitasi
b. Remediasi
c. Restorasi
d. Cara lain sesuai perkembangan teknologi 
Ada beberapa langkah penanganan untuk mengurangi dampak yang ditimbulkan oleh pencemaran tanah, di antaranya adalah:

\section{Remediasi}

Remediasi adalah kegiatan untuk membersihkan permukaan tanah yang tercemar. Ada dua jenis remediasi tanah, yaitu in-situ (on-site) dan ex-situ (atau off site). Pembersihan on-site adalah pembersihan di lokasi. Pembersihan ini lebih murah dan lebih mudah yang terdiri atas pembersihan, venting (injeksi) dan bioremedasi. Pembersihan off-site meliputi penggalian tanah yang tercemar dan kemudian di bawa ke daerah yang aman. Setelah itu di daerah aman, tanah tersebut dibersihkan dari zat tercemar. Caranya yaitu, tanah tersebut disimpan di bak/tanki yang kedap, kemudian zat pembersih dipompakan ke bak/tanki tersebut. Selanjutnya pencemaran dipompakan keluar dari bak yang kemudian diolah dengan instalasi pengolahan air limbah. Pembersihan off-site ini jauh lebih mahal dan rumit (BLH 2015).

\section{Bioremediasi}

Bioremediasi adalah proses pembersihan pencemaran tanah dengan menggunakan mikroorganisme (jamur, bakteri). Bioremediasi bertujuan untuk memecah atau mendegradasi zat pencemar menjadi bahan yang kurang beracun atau tidak beracun (karbondioksida dan air).

Jenis-jenis bioremediasi adalah sebagai berikut:

a. Biostimulasi

Nutrisi dan oksigen dalam bentuk cair atau gas ditambahkan ke dalam air atau tanah yang tercemar untuk memperkuat pertumbuhan dan aktivitas bakteri remediasi yang telah ada di dalam air atau tanah tersebut (BLH 2015).

b. Bioaugmentasi

Mikroorganisme yang dapat membantu membersihkan kontaminan tertentu ditambahkan ke dalam air atau tanah yang tercemar. Cara ini yang paling sering digunakan dalam menghilangkan kontaminasi di suatu tempat. Namun ada beberapa hambatan yang ditemui ketika cara ini digunakan. Sangat sulit untuk mengontrol kondisi situs yang tercemar agar mikroorganisme dapat berkembang dengan maksimal. Para ilmuwan belum sepenuhnya mengerti seluruh mekanisme yang terkait dalam bioremediasi dan mikroorganisme yang dilepaskan ke lingkungan yang asing kemungkinan sulit untuk beradaptasi.

c. Bioremediasi Instrinsik

Bioremediasi jenis ini terjadi secara alami di dalam air atau tanah yang tercemar.

\section{Fitoremediasi}

Fitoremediasi adalah teknologi pembersihan, pengurangan polutan bahaya, seperti logam berat, pestisida dan senyawa organik beracun dalam tanah atau air dengan 
menggunakan bantuan tanaman (hiperakumulator plant). Contoh tanaman hiperakumulator menurut BLH (2015):

a. Thlaspi caerulescens menyerap zink ( $\mathrm{Zn}$ ) dan kadmium (Cd)

b. Alyssum sp., Berkheya sp., Sebertia acuminate menyerap nikel (Ni)

c. Brassica sp. menyerap Sulfate

d. Pteris vittata, Pityrogramma calomelanos menyerap arsenik (As)

e. Pteris vittata, Nicotiana tabacum, Liriodendron tulipifera menyerap mercuri $(\mathrm{Hg})$

f. Thlaspi caerulescens, Alyssum murale, Oryza sativa menyerap senyawa organik (petroleum hydrocarbons, PCBs, PAHs, TCE juga TNT)

g. Brassica sp. menyerap emas (Au)

h. Brassica juncea menyerap selenium (Se)

\section{Kesimpulan dan Saran}

Berdasarkan hasil penelitian dan pembahasan dalam penelitian ini, maka dibuat beberapa kesimpulan sebagai berikut ini:

a. Lahan tanaman Jati dan bekas kebun/semak merupakan lahan budidaya yang memiliki karakteristik lahan kurang lebih sama dengan tingkat keasaman tanah yang rendah.

b. Dari sepuluh parameter yang digunakan untuk menilai status kerusakan tanah di kedua lokasi, terdapat dua parameter yang melebihi batas ambang kritis yaitu $\mathrm{pH}$ tanah dan Daya Hantar Listrik (DHL).

c. Tingkat keasaman $(\mathrm{pH})$ tanah yang rendah karena lahan tersebut merupakan lahan budidaya yang sering digunakan, selain itu lahan tersebut merupakan lahan perbukitan yang memiliki potensi erosi relatif tinggi, sedangkan DHL terkait kandungan garam di dalam tanah, maka berdasarkan nilai DHL di kedua lokasi memiliki kandungan garam yang relatif rendah.

Saran yang perlu menjadi pertimbangan adalah sebagai berikut:

a. Terhadap tanah yang memiliki tingkat keasaman $(\mathrm{pH})$ rendah dapat ditingkatkan dengan cara melakukan pengapuran dan pemupukan.

b. Perlu dilakukan penelitian lanjutan di lokasi kebun Jati dan semak di lahan berbeda sebagai bahan dan informasi pembanding untuk memperkaya kajian ilmiah mengenai status kerusakan tanah pada wilayah yang lebih luas di wilayah Kutai Timur.

\section{Daftar Pustaka}

BLH Kutai Timur. (2006). Penetapan Status Kerusakan Tanah Mengacu Kepada Peraturan Menteri Negara Lingkungan Hidup. Kabupaten Kutai Timur. Sangatta. 
BLH Kutai Timur. (2015). Status dan Potensi Kerusakan Tanah di Kabupaten Kutai Timur (Studi Kasus Kecamatan Rantau Pulung, Batu Ampar dan Long Masangat). Badan Lingkungan Hidup Kutai Timur, Sangatta.

BPS Kutai Timur. (2016). Kutai Timur dalam Angka. Badan Pusat Statistik, Sangatta.

FAO. (2013). Save and Grow Cassava. A Guide to Sustainable Production Intensification. Roma: Food and Agriculture Organization (FAO) of The United Nations.

Hardjowigeno, S. (2013). Ilmu Tanah. Akademika Pressindo, Jakarta.

Hardjowigeno, S. dan Widiatmaka. (2007). Kesesuaian Lahan dan Perencanaan Tataguna Lahan. Gajah Mada University Press, Yogyakarta.

Heryani, N. (1994). Sifat-sifat Tanah dan Klasifikasi. Pusat Penelitian Tanah dan Agroklimat Pertanian, Bogor.

Pemerintah Republik Indonesia. (2000) Peraturan Pemerintah Republik Indonesia Nomor 150 Tahun 2000 tentang Pengendalian Kerusakan Tanah untuk Produksi Biomassa, Pemerintah Republik Indonesia. Jakarta.

Menteri Negara Lingkungan Hidup. (2006). Peraturan Menteri Negara Lingkungan Hidup Nomor 07 Tahun 2006 tentang Tata Cara Pengukuran Kriteria baku Kerusakan Tanah untuk Produksi Biomassa. Menteri Negara Lingkungan Hidup RI. Jakarta.

Pimental, D. (2006). Soil Erosion: A Food and Environmental Threat. Environment, Development and Sustainability. 8: 119-137.

Subroto. (2003). Tanah: Pengelolaan dan Dampaknya. Fajar Gemilang, Samarinda. 